\title{
Ved professor, dr. phil Arne Noe-Nygaards 70-års fødselsdag
}

\author{
KNUD ELLITSGAARD-RASMUSSEN
}

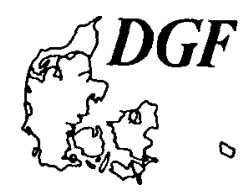

Ellitsgaard-Rasmussen, K.: Ved professor, dr. phil. Arne Noe-Nygaards 70-års fødselsdag. Bull. geol. Soc. Denmark, vol. 27, Special Issue, pp. 56, Copenhagen, July 30th 1978. https://doi.org/10.37570/bgsd-1978-SI-01

A group former students have combined in this volume in honour of Professor Arne Noe-Nygaard on the occasion of his 70th birthday. They offer their most sincere thanks and congratulations and the very best wishes for the future.

Knud Ellitsgaard-Rasmussen, Geological Survey of Greenland, Øster Voldgade 10, DK-1350 Copenhagen $K$, Denmark.

Kære Noe!

Dine gamle elever - nogle af os helt tilbage til dine første år som professor, nogle af os yngre - samles i denne publikation for at hylde dig i anledning af din 70 års fødselsdag.

Du har været knyttet til din post som universitetslærer $\mathrm{i}$ tre år mere end halvdelen af dine leveår. Det er en lang tid. Det føler vi ikke alene, når vi tænker tilbage i åremål, men vi føler det især, når vi ser på, hvad du har udrettet og betydet for dansk geologi.

Nogle af os oplevede de første år i fyrrerne hvor vi kun var fire eller fem studenter, der flokkedes om dig og den viden, som du stod for. Vi oplevede her for første gang dit inspirerende væsen og din evne til at sætte os igang. Vi kunne blive fascineret af en forelæsning over mineralogi eller et emne fra petrografien. Lærebøgerne var få, og lærerens talte ord fra katederet havde stor vægt. Vi var trygge ved din fremstilling. Dine kollokvier blev også skabt i de år. Du havde endnu noget af din sverigestid i kroppen, og det gav kollokvierne et pust fra den skandinaviske geologverden. Vi blev her stillet over for originalarbejder, som vi blev tvunget til at sætte os ind i, selvom indholdet ofte lả ud over vort faglige niveau. Vi lærte måske ikke sả store stofmængder, som studenter i dag, hvor antal af lærere og lærebøger má forekomme os in legio, men vi trivedes og følte, at vi ved udfordringerne sled os igennem til selvstændig stillingtagen til godt eller dårligt. Vi har alle senere fảet gavn af disse udviklende år i den meget snævre kreds, der ikke fyldte meget i auditoriet på Øster Voldgade 7.
Du har altid givet dine studenter stor frihed. Du har tilstræbt at kaste os ud på dybt vand og prøve at lade os svømme. Hvis ikke vi kunne, så måtte vi lære det. Din integration i den enkeltes arbejde var ofte minimal, men altid værdifuld. Det lyder sả enkelt, men det beherskes alligevel ikke af alle lærere. Denne egenskab har nok haft større betydning for dansk geologis trivsel og udvikling $\mathrm{i}$ dette århundrede end noget andet. Der er næppe nogen dansk geolog i nyere tid, der har set så meget trives rundt om sig som Noe. Din situation kan på så mange måder minde om Johnstrups i sidste halvdel af forrige århundrede. Han startede med et indeklemt Museum og Institut, som han gerne ville udvide. Han så en lang række opgaver, der skulle løses såvel i Danmark som i Grønland. Han havde et brændende initiativ og lagde grunden til mange nye projekter og fremskridt. Den bygning, som det lykkedes ham at få skabt på Øster Voldgade 7, måtte du flytte ind i 50 år senere og søge at bygge videre pá. Også du så nye opgaver og udfordringer, der krævede udvidelse og nye medarbejdere. Men det, der ikke altid lykkedes og kunne følges til dørs af din gamle forgænger, lykkedes for dig i rigt mål. Du havde et vågent øje for dine studenters særinteresser og evner, og da du altid har haft en dyb indsigt $i$ geologiens mangeartede verden, forstod du pả rigtig vis at få dine studenter til at dyrke udyrkede områder inden for dit eget geologiske felt. Ud af det gamle Mineralogiske Museum er sprunget et nyt Geologisk Museum af større omfang end det gamle: Institut for Petrologi, Institut for Mineralogi, Institut for Historisk Geologi og Palæonto- 
logi, Institut for Almen Geologi samt Grønlands Geologiske Undersøgelse. Begyndelsen til alle disse institutter lå i dit gamle museum, og det hele er groet ud af denne organisme, som du som museumsbestyrer har været dybt forankret $i$ over halvdelen af dine levedage. En sådan vækst på godt tredive ár er ikke alene skabt af ydre omstændigheder og tidens gunst. Den skyldes også din klare sans for en "geologisk situation «, hvor der byder sig nye muligheder for at finde en bane og et job for en kandidat, eller omvendt hvis en mand har sit område, har du altid med fantasi forstået at kombinere eksisterende muligheder, således at et nyt geologisk arbejdsområde fandt sin plads. Ved sảdanne lejligheder har vi set, hvorledes smålige hensyn og personlige pekuliariteter er blevet overset af dit feltherreblik, der forstod at anskue det egentlige problem nemlig en frugtbar trivsel for faget geologi som en enhed. Alt dette skyldes dog sidst, men ikke mindst, at du gav den enkelte lov til at udvikle sig i frihed.

Jeg har personligt haft den glæde og det privilegium at arbejde $\mathrm{i}$ din nære tilknytning $\mathrm{i}$ fire år mere end halvdelen af min levetid. Det har været godt og let. Oftest har vi haft samme tanker om samme sag. Grundlaget for et frugtbart samvirke har altid eksisteret. Jeg har set, hvordan du har udnyttet tiden. Jeg har set dig sætte tid af til løsning af administrative opgaver ved siden af din pleje af polarisationsmikroskopet. Jeg har set alt det arkivmateriale, som du har udført som grundlag for Grønlands Geologiske Undersøgelses oprettelse, og jeg har set dig deltage $i$ grønlandsarbejdet som feltgeolog $\mathrm{i}$ de år, hvor du importerede nye impulser $\mathrm{i}$ dansk grundfjeldsgeologi ved at invitere Hans Ramberg til at deltage i grønlandsarbejdet. En introduktion, der fik vidtrækkende følger for karteringen af det grønlandske grundfjeld, og bragte det danske grønlandsarbejde ind på en meget stor arena. Jeg har set dig pludselig dukke op i Stockholm for at følge en students arbejde der og drøfte fremtidigt laboratorieudstyr. Jeg har oplevet, hvordan du i en trang periode, hvor du var henvist til reduceret fysisk aktivitet på grund af iskias, brugte dine kræfter med ekstra styrke pá skrivearbejde. »Processer og Materialer« blev sat på skinner, mens du således sad i din sofa. Jeg har fulgtes med dig til møder i ministerier og med myndigheder for at skaffe den fornødne baggrund for grønlandsgeologiens trivsel. Jeg har oplevet dig i den spontanitet, der er så typisk for dig, hvor situationen kræver en hurtig reaktion og en evne til uden varsel at stå op og sige noget rigtigt, som vinder gehør hos modtageren.

Mine kammerater kender andre situationer, som de har oplevet på samme måde. For alle har din ærlighed og dit udadvendte sind betydet meget både som forsker, lærer og ven. Dit væsen har vundet geologien mange venner. Dit image er blevet rodfæstet i de kredse, der står geologien nær, og som vi ikke kan klare os uden. Det er dig, man kender, og det er dig, man ofte retter en første henvendelse til, og det er din reaktion, der ved så mange lejligheder har haft betydning for slutresultatet.

Dine gamle elever er glade for at kunne hylde dig på din 70 års fødselsdag. Vi kender alle din indsats for det nordiske og det internationale arbejde, dit arbejde i Island bl.a. for at medvirke til oprettelsen af Nordisk Vulkanologisk Institut, din indsats som præsident for geologkongressen i København i 1960, der affødte den geologiske union og sidst, men ikke mindst, den lange liste over geologiske afhandlinger, som du til stadighed har øget. Men det har først og fremmest været vort ønske at bringe dig en hyldest og tak for det, du har betydet for os, og for den hjælp du igennem så mange år har ydet dine gamle elever på de poster inden for geologien, som nu blev deres andel i det for dig så væentlige: det geologiske helhedsbillede.

Vi bringer dig vor hjerteligste tak og lykønskning.

Vi bringer dig alle gode ønsker for de kommende år. 